\title{
Creating Mutual Fund Transparency: The Elimination Of Deceptive Communication
}

\author{
Brian D. Fitzpatrick, Rockhurst University, USA
}

\begin{abstract}
While the SEC debates the overall merits of forming mutual fund company boards with an independent chairman to go along with $75 \%$ make-up of independent board members, I question how this is going to create more transparency for the individual investor. The real culprit is the flexibility given to mutual fund companies in allowing them to set fees as permitting trading within funds has confused the true cost to the consumer and has added insult to injury. Dr. Edward $O$ 'Neal at Wake Forest states that "the average fund managers cannot recoup these expenses in the form of better performance." Gaspar, Massa and Matos (2006) brilliantly show that mutual fund families tend to charge various levels of fees on its member funds, forcing different funds to contribute unequally to the total profit. They found that during the January 1991 to July 2001 time period, high value funds (i.e., high fees or high past performance) are favored inside fund families by 6-28 basis points of extra net-of-style performance per month $(.7 \%-3.3 \%$ per year) relative to the low value funds (i.e., low fees or low past performance), based on the criteria they used (i.e., fees or past performance). How can all these deceptive practices be eradicated? The author proposes a five-step "absolute" process in order to create mutual fund transparency: the elimination of all soft dollar arrangements; creation of a mutual fund separateness statue to eliminate what Gaspar, Massa and Matos (2006) call the strategic Cross-Fund Subsidization; terminate all 12-B1 fees; eliminate all "rolling performance periods" by forcing one-year calendar performance periods with mandatory fee return to investors if the manager underperforms; and outlaw all front-end and back-end loads, thus forcing marketers to charge a direct commission. The goal of any transparent system is to protect the consumer, and the individual investor can only be protected by implementing "absolute standards" that will allow no "wiggle room" for mutual fund companies.
\end{abstract}

Keywords: 12-B1 fees, cross-fund subsidization, expense ratios, rolling performance periods, absolute standards, high value funds, low value funds

\section{INTRODUCTION}

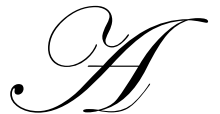

recent Securities and Exchange Commission rule (22c-2), implemented in 2005 in light of market timing criticism, was meant to ensure that mutual funds possess information, such as transaction data and shareholder identity, that would be necessary to help enforce restrictions. The Wall Street Journal estimates that 60 to 70 percent of the required agreements with intermediaries were already in place weeks before the deadline. This market-timing rule does not mandate funds to levy penalties on early redemptions, but it does require the mutual fund boards to entertain whether redemption fees should be imposed. It should come as no surprise that leading up to the deadline, many mutual funds tacked on redemption fees to their funds or commenced omnibus accounts, like 401(k) plans to implement fees. This is yet another example of how the intent of the law is distorted and ultimately causes less transparency while tacking on additional fees to the investors. WSJ (April 23, 2007) 
SEC Chairman, Christopher Cox, indicated that the agency wishes to reissue and finalize a fundgovernance rule this year (2007), following closely federal administrative procedures. The proposal is to insist that $75 \%$ of fund directors, including the chairman, should separate from any ties to the mutual fund company. It is interesting to note that this fund-governance rule, first touted by the SEC under then-chairman William Donaldson in 2004, was challenged twice by the US Chamber of Commerce and was rejected twice by a federal appeals court, which lambasted the SEC for failing to seek public sentiment on both the rule's cost and benefits. WSJ (April 16, 2007)

The SEC is also re-examining the so-called $12 \mathrm{~b}-1$ fees, which allow mutual funds to charge customers to directly pay for marketing and distribution expenses. These fees were approved in 1980 because the mutual fund industry was in danger of shrinking, with expectations that they would only be implemented temporarily in order to assist in spreading the fees among a larger investor pool. Like most attempts by government to appease everyone, the investors end up paying a dear price in greater fees and diminished transparency. Obviously, the original premise of $12 \mathrm{~b}-1$ logic is highly suspect in today's milieu. Ironically, many mutual funds continue to impose $12 \mathrm{~b}-1$ fees after shutting their fund options down to new investors. WSJ (April 16, 2007)

SEC chairman Christopher Cox is absolutely correct when he states that there must be a more concerted effort to replace this "purge of legalese and gobbledygook" from mutual fund documents and create transparency for the investors by giving them plain English. I will argue that the only way to ultimately promulgate a truly transparent system for the investor is to abide by absolutes and not compromises. Force the mutual fund companies to adjust and not the investors. The goal of the government should be to protect the investors, not the mutual fund companies. WSJ (April 16, 2007)

Jack Murphy and Julien Bourgeois (2006) give an excellent summary for mutual fund performance fees and describe how these legal constraints are designed to work. Once again, reality is different than intent and until absolute guidelines are implemented, the environment will favor the mutual fund conglomerates and not the investing public. According to Murphy and Bourgeois (2006) the SEC issued a 1972 Interpretative Release and formed Rule 205-1 and Rule 205-2 under the Advisors Act which pertains to mutual fund performance fees. These rules are designed to provide guidance on how performance fees (i.e., fulcrum fees) should be calculated and charged. The exception to the principle under these rules (specifically 205-2(c) provides an exception to the basic principle of the laws, and states that the specific period over which the net asset value is averaged to calculate the fulcrum fee may differ from the period which the net asset value is averaged for calculation purposes of the performance adjustment.

By allowing rolling performance periods of 12,24 or 36 months, the SEC in practice allows fund companies to collect advisory fees at the end of each sub period (i.e., monthly, quarterly or semi-annual periods). In practice, mutual fund boards know that the impact of performance adjustment, which is figured on net assets averaged over the performance period, will relate much more to past variations in the level of net assets due to shareholder activity in the fund and past performance utilizing a longer performance period (several years possibly), than with a shorter time period, such as one year. Obviously a shorter period will force the performance adjustment to be tied more to current assets and recent performance. The flexibility given to the mutual fund companies is allowing them to materially impact the aggregate amount of advisory fees paid by the fund. I strongly recommend that all rolling performance laws be eliminated, and only one-year time periods (calendar year only) should be implemented. In addition, once a benchmark index is implemented, the fund cannot change without SEC and shareholder approval. (Murphy and Bourgeois 2006)

John Bogle who was founder of the Vanguard Group of funds maintains that "funds are operated largely in the interests of their management companies, rather than in the interest of their shareholders." Mr. Bogle is in strong support of the new proposed SEC requirement requiring the chairman of a mutual fund company to be independent as well as supporting the 75 percent independent board rule. This is all designed to create more transparency for the shareholder and I hope it does, but I argue that absolute measures must be implemented to guide these so-called independent chairs by allowing them no wiggle room. Remember that the intent should be to protect the consumer and not the mutual fund company. (Curtis 2006) 
The main question is how much are you really paying for your mutual fund? A sad commentary is that even if you try to find out, you simply cannot do it. We know that high expenses will drag down your investment return. Professor Edward O'Neal from Wake Forest University states that "on average, fund managers cannot recoup these expenses in the form of better performance." He concludes by saying "rampant price-gouging by mutual fund advisors costs shareholders \$9 billion a year." Jane Bryant Quinn (2007) Professor O’Neal from Wake Forrest University and law professor Mercer Bullard from Ole Miss reviews a discussion on fees which the mutual fund shareholder cannot determine. They review various arrangements: the cost of buying and selling stocks; the cost of the spread; soft dollars revenue sharing; and lack of communication. Funds pay commissions to large institutional brokers and the more a fund trades, the more brokers earn. The professors checked ten fast-trading funds and found that brokers were paid an incredible 1.67 percent of your assets in commissions. The difference of the spread goes to the brokerage companies and O'Neal estimates spread costs at two percent per year for large funds and 1.7 percent for fast-trading funds. When Dr. O'Neal added up the expense ratio, the brokerage fees and the spreads for certain funds, he found that you would have paid in 2001, approximately .21 percent for the no-load Vanguard 500 index, 1.01 percent for the Davis New York Venture Fund (A shares), 1.64 percent for Fidelity Contrafund and 8.59 percent for PBGH large cap fund. Their study only incorporated "index type mutual funds;" if index funds pose this much confusion, I beg to think how much more in hidden fees the consumers are paying when they invest in "normal mutual funds." Many fund managers intentionally overpay for brokerage commissions and in exchange will receive "free" research and other amenities (e.g., computers and data services). Obviously these soft dollar arrangements will keep reported expense ratios down, but will clandestinely drive your costs up. With revenue sharing agreements, brokers are compensated to sell "selected funds" to customers. Directed brokerage takes your money and rewards the most successful selling brokers. Did you really think that your financial counselor had your best interests at heart? Supposedly the SEC is banning directed brokerage but a major challenge is how to communicate these costs and conflicts of interest in a simplified way. Paul Roye who is the SEC's director for the Division of Investment Management, communicates these conflicts of interest; he claims that the SEC will make changes if people find the forms unclear. Many investors simply do not have a clue of where to begin to look for conflicts of interest. (Jane Bryant Quinn 2007)

The Zero Alpha Group, which comprises various independent investment advisory firms, found that the management and marketing fees that mutual funds routinely disclose to investors (i.e., expense ratios and $12 \mathrm{~b}-1$ fees) seriously understate mutual funds' "true costs" due to hidden transaction fees which are reflected indirectly in the funds' performance. O'Neal and Bullard (2006) who conducted the study, uncovered that 43 percent of the funds' expenses were omitted from their expense ratios. In a few cases, the portfolio transaction costs were five to six times greater than published expense ratios. Dr. O'Neal stated that the 30 top domestic equity funds doled out $\$ 643$ million in commissions in 2001. Professor O'Neal did acknowledge that investors can determine funds' brokerage commissions paid by asking for the "Statement of Additional Information" from the funds, but most investors do not even know it exists and unless it is requested, the information is not supplied. Dr. O'Neal also found that ten of the highest turnover funds in the United States (i.e., equal to or greater than 500 percent turnover per year), possessed higher hidden trading costs and these funds were higher than and sometimes more than twice as high as the funds' published expense ratios. According to Mercer Bullard who is president of Fund Democracy and assistant professor of law at Ole Miss, "Congress should move quickly to ensure that investors are given full disclosure." He concludes that their study proves that expense ratios are indeed misleading. IOMA's Report on Managing 401 (k) Plans (April 2004)

One of the most misunderstood and abusive practices toward investors is the favoritism shown within the mutual fund families. Jose-Miguel Gaspar, Massimo Massa and Pedro Matos' (2006) brilliant work "Favoritism in Mutual Fund Families? Evidence on Strategic Cross-Fund Subsidization" in the Journal of Finance thoroughly proves that the mutual fund industry generates distortions in delegated asset management. They show that fund families strategically transfer performance across member funds in order to credit those more likely to increase overall company profits. They note that families tend to charge a different level of fees on its member funds, forcing different funds to contribute unequally to the total profit. The empirically accepted positive sensitivity of investor inflows to performance provides an incentive for the fund family to improve the performance of some funds, namely the high fee funds (i.e., high fees or high past performers) at the expense of the low fee funds (i.e., low fees or low past performers). Even though investors would not necessarily benefit when new capital flows to high fee funds and/or investors in low fee funds are induced to shift toward high fee funds, the family of funds 
procures increased profits. This "strategic cross-fund subsidization" game stems from the convex relationship between past performance and investors' flows. Ironically, the authors show from a fund family perspective that the convexity implies that the expected assets of a family are greater if it produces one top performing and one bad performing fund than if it creates two average performing funds. Massa (2003) shows how this impact is further amplified when investors pick a fund family first, then they choose which fund to invest in.

Nanda, Wang and Zheng (2003) concludes that a "star performing fund" will have a positive spillover effect on the inflows of other same-family funds, even if there seems to be no negative effect from an under performing fund. It would be obvious that cross-fund subsidization works to the detriment of low performing fund investors. Gaspar, Massa and Matos (2006) show that high value funds are favored inside fund families by 6-28 basis points of extra net-of-style performance per month (.7 percent -3.3 percent per year) relative to the low value funds, depending on the criteria they used (i.e., fees or past performance). They powerfully show that cross-fund subsidization is indeed an "in-family phenomenon." Their data source was the Center for Research in Security Prices (CRSP), Survivor-Bias Free U.S. Mutual Fund database during the January 1991 to July 2001 time period.

Gaspar, Massa and Matos (2006) conclude convincingly that if families can shift performance from low value to high value funds, then they will gain and investors in low value funds will suffer. It is not known whether the much hyped benefits of economies of scale and scope in the areas of research, trading and execution, investor searching, and possible lower distribution costs actually benefits the investors. In an altruistic world when fund families pass on these savings to consumers, perhaps the value-destruction coming from cross-fund subsidization is minimal; however, this seems unlikely in the real world. It is extremely doubtful that the average investor would always be able to select the funds which are considered high value. I whole heartedly agree with these authors when they state that it is doubtful that investors cannot profitably benefit from the present existence of family strategies.

\section{RECOMMENDATIONS}

It is imperative to implement absolute guidelines for mutual fund companies in order to truly protect the investment community. True Transparency can only take place if the law allows no wiggle room for the mutual fund companies. I always ask how someone gets paid, and if there is any conflict of interest then eventually the investor will be hurt when the mutual fund companies push the envelope. I am proposing five strict rules that need to be implemented in order to end deceptive communication practices within the mutual fund industry. They must be absolute, otherwise the companies will take advantage of any wiggle room. The five absolute recommended changes to create Mutual Fund Transparency are as follows:

1. Immediately eliminate all soft dollar arrangements, thus eradicating any conflicts of interest. This will force companies to be more efficient because they will have difficulty passing any inflated fee structure on to the customer.

2. Outlaw the so called cross-fund subsidization process (see Gaspar, Massa and Matos 2006). 3) Eliminate distribution fees (i.e., 12b-1 fees) which were permitted beginning in 1980 as a temporary measure to help ailing mutual fund companies. The marketing entities will adjust and they will produce more efficiently when the law mandates such behavior.

3. Implement discrete time periods for all "performance pay" funds. One-year performance data based on only calendar year time periods should be mandated, and funds which desire this type of system must also return fees back to the investor if in any year, they under perform. Immediately eliminate all "rolling performance periods," and require that the index fund implemented for performance benchmarking cannot be altered once chosen unless there is $2 / 3$ majority approval by shareholders and SEC acceptance.

4. Outlaw front-end loads as well as back-end loads. If investors truly wish for spreads, let them buy closed ended funds. Performance should automatically sell the funds, so let the markets work their magic in selling performing funds, and require investment professionals to improve the performance of nonperforming funds. 


\section{CONCLUSION}

The lack of transparency phenomenon should never fall on the investor if we are to promulgate an ethical and clear investment standard within the mutual fund industry. Implementing absolute guidelines is the only way to protect the consumer; we need to offer complete transparency. Rational human behavior works well in describing economic models, but unfortunately reality paints a picture of selfish self-centered behavior. Research continues to show that expense ratios do not always adequately tell the consumer how much they are really paying for the manager to invest his/her money (see Gaspar, Massa and Matos 2006, Murphy and Bourgeois 2006, O'Neal and Bullard 2006, O'Neal 2007). Let us as a nation protect the consumer by creating pure transparency within the mutual fund industry. The author proposes a five-step "absolute" process in order to create mutual fund transparency: the elimination of all soft dollar arrangements; creation of a mutual fund separateness statue to eliminate what Gaspar, Massa and Matos (2006) call the strategic Cross-Fund Subsidization; terminate all 12-B1 fees; eliminate all "rolling performance periods" by forcing one-year calendar performance periods with mandatory fee return to investors if the manager underperforms; and outlaw all front-end and back-end loads thus forcing marketers to charge a direct commission. The goal of any transparent system is to protect the consumer, and the individual investor can only be protected by implementing "absolute standards" that will allow no "wiggle room" for mutual fund companies.

\section{AUTHOR INFORMATION}

Brian D. Fitzpatrick is a professor of finance for the Helzberg School of Management at Rockhurst University in Kansas City, Missouri. He earned his Ph.D. in Finance with a concentration in Investments from Saint Louis University. Dr. Fitzpatrick spent ten years in the Investment field including positions with two major Wall Street wire houses, as well as serving as senior vice president for both Financial Corporation of America and Commerce Bancshares. Brian has won the Rockhurst University's Teaching Excellence Award, and he has published in nine different fields.

\section{REFERENCES}

1. Burns, J. "SEC Reviews Fund Governance, Fees," The Wall Street Journal, Section C14, April 16, 2007.

2. $\quad$ Curtis, C. "A Radical Act at the SEC?" Securities Industry News, October 2, 2006.

3. $\quad$ Elton, E. Gruber, M., and Busse, J., “Are Investors Rational?” Journal of Finance, 59:1, 2004, 261-288.

4. Gaspar, J.M., Massa, M., and Matos, P. "Favoritism in Mutual Fund Families? Evidence on Strategic Cross-Fund Subsidization," The Journal of Finance, February 2006, 73-104.

5. Haslem, J. “A Tool for Improved Mutual Fund Transparency,” The Journal of Investing, Fall 2004, 54-64.

6. Hillman, R. "Mutual Funds: Additional Disclosures Could Increase Transparency of Fees and Other Practices" Testimony before the subcommittee on Capital Markets, Insurance and Government Sponsored Enterprises, Committee on Financial Services, House of Representatives, GAO document 03-909T Highlights, 1-11.

7. Massa, M. "Why So Many Mutual Funds? Mutual Fund Families, Market Segmentation and Financial Performance," working paper, INSEAD, 1998.

8. Massa, M. "How Do Family Strategies Affect Fund Performance? When Performance Maximization Is Not The Only Game In Town," Journal of Financial Economics, 67, (2003) 249-304.

9. Maxey, D. "Market-Timing Gets More Expensive for Some," The Wall Street Journal, Section C8, April 23, 2007.

10. Morrow, R. “Analysis Finds Fees Disclosed by Funds Understate True Costs” IOMA's Report on Managing 401(k) Plans, April 2004, 1-13.

11. Murphy, J. and Bourgeois, J. "Mutual Fund Performance Fees: Discussion and Observations," The Investment Lawyer, Vol. 13, No. 11, November 2006, 1-17.

12. Nanda, V., Wang, J., and Zheng, L. "Family Values and the Star Phenomenon," working paper, University of Michigan.

13. O’Neal, E. and Page, D. "Utility Sector Mutual funds: Performance and Dividend Policy Implications," Managerial Finance, Vol. 28:12, 2002. 
14. O'Neal, E. and Bullard, M. "The Costs of Using a Broker to Select Mutual Funds" This study was commissioned by the Zero Alpha Group (ZAG), November 2006, www.funddemocracy.com.

15. O'Neal, E. "Beware of Falling Stock," Ann Arbor News, 2007.

16. Quinn, J. B. "New Light on Hidden Fees," www.msnbc.com February 16, 2007.

\section{NOTES}

